Yasin Tok

Preschool Teacher

Zubeyde Hanim Kindergarten

Malatya, Turkey

Dr. Merve Ünal ${ }^{2}$

Inonu University, Faculty of Education

Departman of Primary Education

Malatya, Turkey
Original scientific paper

UDC: 371.136

DOI: $10.5937 /$ IstrPed2002203T

\title{
EXAMINING THE CORRELATION BETWEEN RESILIENCE LEVELS AND MATH AND SCIENCE PROCESS SKILLS OF 5-YEAR-OLD PRESCHOOLERS*
}

\begin{abstract}
The aim of this study is to determine whether the resilience levels and mathematics and science process skills of 5 -year-old preschoolers vary significantly based on independent variables (gender, number of siblings, education level of the mother, education level of the father, and family income level) and to detect the correlations between them. The sample of the study consisted of 384 children. "Child Information Form, Risk Factors List, Early Childhood Resilience Scale, Early Childhood Mathematics Education Content Standards Scale, and Science Observation Form" were used as data collection tools. In the study, it was determined that there was a significant difference between the resilience levels of children and gender, education level of the father, and family income level. A significant difference was observed between the mathematical skills of the children and the number of siblings, parental education level, and family income level. Also, a significant difference was determined between the science process skill levels of the children and the number of siblings, family income level, and father's education level. There was a moderate positive correlation between resilience and mathematical skills and a high positive correlation between resilience and science process skills. In addition, it was concluded that the resilience levels of children were a significant predictor of their mathematics and science process skill levels.
\end{abstract}

Keywords: Math skills, preschool education, resilience, science process skills.

\section{INTRODUCTION}

The preschool period is the most valuable time for children to acquire basic knowledge, skills, and habits forming their personality and thus laying a foundation in all areas of development (Sahan Aktan \& Onder, 2018; Tastepe, 2012). Meeting the basic needs of young children and establishing and maintaining positive relations with the circle during these years are essential for successful development in early childhood (VanderVen, 2008). However, every child does not have this support adequately. Individual, familial, environmental and social risk factors for the development of the child include diseases of parents, indifferent parental attitudes,

\footnotetext{
*This article is derived from the master's thesis study prepared by Yasin Tok under the guidance of Asst.
} Prof. Merve Unal. 
negative child-rearing styles, divorce, single-parent family structure, unemployment, neglect, abuse, war, death, natural disasters (such as fire and earthquake), family conflict, social violence, homelessness, poverty, drug addiction, alcohol addicted parents, involvement in crime, diseases, low education level, and premature birth (Benard, 1993; Brackenreed, 2010; Gurgan, 2006; Masten \& Cicchetti, 2016; Masten \& Powell, 2003; Newman, 2002; Zolkoski \& Bullock, 2012). In this context, children who are exposed to any of these risk factors are also considered to be at risk or disadvantaged.

Environments become more and more dangerous for children with each passing day. The number of disadvantaged children or those at risk has been continuously increasing. In addition, academic skill levels of such children decrease and their discipline and social behaviours are adversely affected (Condly, 2006; as cited by Erdem, 2017) by today's circumstances. Only a small number of children are raised under ideal living conditions. For example, conditions such as poverty, violence, family conflicts, and illnesses might negatively influence the cognitive, social, and emotional development of children. Therefore, these children may not reach their full potential during the following years and adulthood (Zolkoski \& Bullock, 2012). It can be asserted that while some children may fail in such situations, some others can struggle with problems and succeed. Children, who are able to manage to overcome difficulties despite some negative events, situations, and experiences, have resilience (Abasli \& Polat, 2019). The concept of "Resilience" is expressed along with various terms such as self-recovery power, psychological stability, and psychological endurance (Sahan Aktan \& Onder, 2018). Resilience is defined as the positive adaptation by overcoming the matter after exposure to risky or negative situations (Cicchetti, 2010; Luthar \& Cicchetti, 2000; Masten \& Cicchetti, 2016; Masten \& Coatsworth, 1998; Masten \& Powell, 2003; Richardson, Niger, Jensen \& Kumpfer, 1990; Zolkoski \& Bullock, 2012).

If children and adolescents cannot receive the basic human needs such as social support, care, and love in their family setting, schools should give them a chance to establish positive relationships (Benard, 1993). In early childhood, qualified educational opportunities should be offered to children under adequate and appropriate conditions. Because adverse conditions in any physical and social environment during early childhood may affect the physical and mental structure of children in the following years (Sahan Aktan \& Onder, 2018). In addition, the development areas and academic success/skill of children affect one another. Sufficient gains during the early periods can prevent possible academic difficulties and developmental problems in the future. For this reason, positive results can be obtained in the coming years by applying for intervention programs or providing support services to children at risk and their families (Erdil, 2010). In this context, academic success can be an important factor in reducing the effect of the risks exposed by children, who are considered to be at risk or disadvantaged, since early childhood and raising them as strong and indomitable adults of the future.

Cognitive abilities affect problem-solving, experience evaluation, and other aspects of adaptation in children (Masten, Best \& Garmezy, 1990). Considering that it is a dynamic adaptation process (Masten \& Powell, 2003), it can be asserted that the adaptation processes of children interact with their early academic skills and success. For example, most studies examining the correlation between socioeconomic status and academic success have reported that low academic success is associated with major socioeconomic deficiencies (risk factors). However, some studies have revealed that children at risk from families with low socioeconomic level have higher academic success than others. In this context, success is associated with individual differences and motivation. Therefore, high motivation positively 
affects academic success by eliminating the risk factor (resilience) (Erdil, 2010). In this case, it can be asserted that the resilience levels, science learning processes, and early academic skills of children support each other.

In the literature, it was stated in the study conducted by Ogelman, Secer, Alabay, and Ucar (2012) with 5-6-year-old children that the cognitive development of children was an important factor affecting their social development/skills. The findings of the study conducted by Erturk Kara (2017) with 60-72 month-old children indicated that the social skills of the children were related to their math skills. In the study conducted by Fredricks, Blumenfeld, and Paris (2004) about school participation, they indicated that social and behavioural participation was associated with higher success. In their study, McClelland, Morrison, and Holmes (2000) emphasized the role of social skills related to learning in early academic problems of children at risk and their findings highlighted the importance of early social skills in figuring out a successful school transition and early academic success. Children with low social skills had lower academic skills. From this point of view, weak social skills are a risk factor for low academic success and school attendance. In this context, the role of the resilience factor, which is considered as the social/psychological empowerment of children at risk, cannot be denied. In the study conducted by Abasli and Polat (2019) with secondary school students about emotional autonomy and resilience, they determined a positive significant correlation between students' grade point averages (academic success) and resilience levels. The results of their study indicated that as students' academic success (grade point average) increased, their resilience levels also increased. In this context, it can be asserted that it is important and original to examine the resilience levels and early academic skills of 5-year-old preschoolers in terms of math and science process skills and this study would contribute to child-rearing and preschool education.

\section{Aims of the Study}

The aim of this study was to determine whether the resilience level and math and science process skills of 5 -year-old children attending preschool education differ based on independent variables and to detect the correlations between them. The research questions were listed as follows;

1. Is there a significant difference between the resilience levels of 5-year-old preschoolers and gender, number of siblings, education level of parents, and family income level?

2. Is there a significant difference between the mathematical skills of 5-year-old preschoolers and gender, number of siblings, education level of parents, and family income level?

3. Is there a significant difference between the science process skills of 5-year-old preschoolers and gender, number of siblings, education level of parents, and family income level?

4. Is there a significant correlation between the resilience levels and mathematical skills of 5-year-old preschoolers?

5. Is there a significant correlation between the resilience levels and science process skills of 5-year-old preschoolers?

6. Are the resilience levels of 5-year-old preschoolers a significant predictor of mathematics and science process skills? 


\section{METHOD}

The quantitative research model, which is a model providing results using analytical and inferential statistics (Cohen, Manion \& Morrison, 2005), was used in the study. A descriptive survey method based on the quantitative research model was also employed in the study. Descriptive research method enables to describe an existing situation or event as it is without making any intervention (Karasar, 2015). Correlational research type, which is carried out to determine the correlations between two or more variables, was used in the study to determine the correlations between variables (Buyukozturk, Kilic Cakmak, Akgun, Karadeniz \& Demirel, 2012).

\section{Sample}

Criterion sampling, one of the purposeful sampling methods, was used in the study to determine the sample. The sample of the study consisted of 5-year-old children who had normal development, attended preschool education in independent kindergartens and nursery classes affiliated with the Ministry of National Education, met at least one risk factor in the list of risk factors used as criteria, and were adapted to the environment. In criterion sampling method, units meeting the criteria determined for sampling are included in the sampling (Buyukozturk et al., 2012). Considering the number of preschoolers residing in the central districts of Malatya province (16876) as of 2019, the number of children to be included from the population to the sample was calculated as 376 .

During the data collection process, it was targeted to reach a total of 450 children who met the list of risk factors and had normal development because of considering possible difficulties and data losses. The data were collected between April and June 2019 so that the teachers would get to know children better and the process of children gaining early academic skills would be considerably realized. 427 data collection forms were returned and 43 forms were invalid due to several reasons and thus the study was conducted with the data obtained from 384 data collection forms.

Table 1. Frequency Distribution of Risk Factors of the Children in the Study

\begin{tabular}{lc}
\hline Risk Factors & Frequency \\
& (n) \\
\hline Poverty & 81 \\
Physical abuse & 31 \\
Emotional abuse & 28 \\
Sexual Abuse & - \\
A family member with mental disorder & 13 \\
A family member with a serious health problem & 29 \\
The death of significant other in the child's life (Brother, grandmother, grandfather, etc.) & 24 \\
Family conflict (discussion, fighting parents) & 62 \\
Living on the street (like in a tent) & - \\
Malnutrition (starvation of the child) & 7 \\
Living in high crime neighbourhoods & 1 \\
Witnessing a terrorist incident & 4 \\
Fear of being exposed to a terrorist incident & 5 \\
Single-parent family structure & 49 \\
A family member attempting or committing suicide & - \\
Prolonged separation from his/her mother (the mother's separation from her child due to & 14 \\
long-term work or health problem) & 15
\end{tabular}


The child is born prematurely (born before normal birth) 16

$\begin{array}{ll}\text { Death of Mother or father } & 21\end{array}$

Divorce $\quad 44$

$\begin{array}{ll}\text { Mother or father leaving home } & 21\end{array}$

$\begin{array}{ll}\text { Negligence } & 56\end{array}$

Very strict parenting attitude $\quad 42$

$\begin{array}{ll}\text { Violence at home } & 38\end{array}$

Unemployment problems (family member responsible for caring) 49

$\begin{array}{ll}\text { Adolescent mother (14-19 years old) } & 27\end{array}$

Living under very bad physical conditions (very bad physical conditions of the house) 23

One of the family members is an alcoholic 4

$\begin{array}{ll}\text { One of the family members is a drug addict (drugs or medicine) } & 1\end{array}$

Witnessing/being a victim of a natural disaster

Social exclusion of the family $\quad 9$

$\begin{array}{ll}\text { Child's exposure to social exclusion } & 24\end{array}$

Mother's exposure to high levels of stress during pregnancy and after birth 22

$\begin{array}{ll}\text { Parents with low education level } & 61\end{array}$

$\begin{array}{ll}\text { A family member being sentenced to prison or having a criminal record } & 7\end{array}$

According to the list of risk factors of the children included in the study, the highest risk factor was "Poverty" with 81 times. The teachers marked "Family Conflict (discussion, fighting parents)" 62 times and "parents with low education level" 61 times. On the other hand, the factors "Sexual abuse", "Living on the street (like in a tent)", "A family member attempting or committing suicide", and "Witnessing / being a victim of a natural disaster" were not marked at all.

Table 2. Distribution of Demographic Information of the Children

\begin{tabular}{|c|c|c|c|}
\hline Variable & Group & Frequency (n) & Percentage (\%) \\
\hline \multirow[b]{2}{*}{ The gender of the child } & Girl & 189 & 49.2 \\
\hline & Boy & 195 & 50.8 \\
\hline \multirow{4}{*}{$\begin{array}{l}\text { Educational status of the } \\
\text { mother }\end{array}$} & Literate-Primary school & 78 & 20.3 \\
\hline & Secondary School & 39 & 10.2 \\
\hline & High school & 131 & 34.1 \\
\hline & University & 136 & 35.4 \\
\hline \multirow{4}{*}{$\begin{array}{l}\text { Educational status of the } \\
\text { father }\end{array}$} & Literate-Primary school & 63 & 16.4 \\
\hline & Secondary School & 37 & 9.6 \\
\hline & High school & 129 & 33.6 \\
\hline & University & 155 & 40.4 \\
\hline \multirow{4}{*}{ The number of siblings } & Single child & 54 & 14.1 \\
\hline & 1 & 171 & $44 \cdot 5$ \\
\hline & 2 & 107 & 27.9 \\
\hline & 3 or more & 52 & 13.5 \\
\hline \multirow{5}{*}{ Family income level } & Very high & 15 & 3.9 \\
\hline & High & 141 & 36.7 \\
\hline & Medium & 137 & 35.7 \\
\hline & Low & 77 & 20.1 \\
\hline & Very low & 14 & 3.6 \\
\hline Total & & 384 & 100 \\
\hline
\end{tabular}


When the distributions of the children based on gender were examined, it was observed that while $189(49.2 \%)$ of the participants were girls, 195 (50.8\%) were boys. Concerning the educational status of the mothers of the children, it was determined that $78(20.3 \%)$ of the mothers were literate-primary school graduate, 39 (10.2\%) were secondary school graduate, 131 (34.1\%) were high school graduate, and 136 (35.4\%) were university graduates. When the educational status of the fathers of the children was examined, it was observed that 63 (16.4\%) of the fathers were literate-primary school graduate, 37 (9.6\%) were secondary school graduate, 129 (33.6\%) were high school graduate, and 155 (40.4\%) were university graduates. When the distribution of the sample in terms of the number of siblings was examined, it was observed that $54(14.1 \%)$ of the participants were single children, 171 (44.5\%) had 1 sibling, 107 (27.9\%) had 2 siblings, $52(13.5 \%)$ had 3 or more siblings. In terms of family income levels, 15 (3.9\%) had a very high-income level, 141 (36.7\%) had a high-income level, 137 (35.7\%) had a medium-income level, 77 (20.1\%) had a low-income level, and 14 (3.6\%) had a very low-income level.

\section{Data Collection Tools}

\section{Child Information Form}

The form prepared by the researcher was filled by the teachers based on the child's information written on the candidate registration form to determine the demographic information of the child such as gender, number of siblings, education level of parents, and family income level.

\section{Risk Factors List}

Based on the information obtained from the individual interview (E. Ersay, personal communication, February 4, 2019), the "Risk Factors List" developed by Ersay (2016) lists thoroughly the negative factors that may disrupt the development of children in the preschool period, affect their lives negatively, and cause problematic behaviors. The list of risk factors has 35 items that are ranked according to the frequency of occurrence. The list of risk factors was used as a precondition for determining resilience in the preschool period. Some risk factors in the scale are poverty, malnutrition (starvation of the child), divorce, and an alcoholic family member.

\section{Early Childhood Resilience Scale (ECRS)}

Based on the information received during the individual interview, the "Early Childhood Resilience Scale" (ECRS), developed by Ersay (2016), aims to measure the degree of positive development in preschoolers exposed to negative experiences. ECRS had originally 51 items. An exploratory factor analysis was performed by Ersay and Erdem (2017) on 375 data sets in Sanliurfa. Before repeating the exploratory factor analysis, 12 items whose factor loads were not suitable were omitted from the scale. In the later analysis, it was found that 39 items on the scale showed a single-factor structure. The single-factor structure in the last version of the scale accounts for $52.528 \%$ of the total variance. The Cronbach's alpha coefficient of the answers given to 39 items in the last version of the scale was calculated as 0.976 . In the validity and reliability study of the scale conducted in Ankara province, the confirmatory factor analysis was performed on the data collected with ECRS (Ersay, 2018). In the analysis made with 367 datasets, missing data were examined and 18 observation datasets were removed. It was determined that the correlation between the items was below 0.80 and there were no multiple connection problems. After examining the assumptions, the analysis was continued with the data of 349 children. It was observed that the factor load values of the items in the 
scale ranged between 0.71 and 0.88 . These results revealed that there were medium-high level correlations between child resilience levels and items.

As a result of the reliability analysis made with the data of this study, the Cronbach's alpha coefficient of the overall scale was found to be .981 . This result confirms that the measurement tool is very reliable.

\section{Early Childhood Mathematics Education Content Standards Scale (MCSS)}

It was developed by Tastepe and Temel (2013) to measure and evaluate mathematics education content standards. MCSS consists of a total of 27 items and 4 subscales as Number /Counting Process Awareness (9 items), Measurement Awareness (5 items), Geometry and Spatial Logic Awareness (7 items), and Data Collection and Statistical Awareness (6 items). Total variance explained by 4 factors of MCSS is .74 . As a result of the reliability analysis, the Cronbach's alpha coefficients were found as .96 in the Number/Counting Process Awareness subscale, .91 in the Measurement Awareness subscale, .95 in the Geometry and Spatial Logic Awareness subscale, .95 in the Data Collection and Statistical Awareness subscale, and .97 in the overall scale.

\section{Science Observation Form (SOF)}

"Science Observation Form", adapted by Kuru and Akman (2017), is a three-point Likert (Always, Sometimes, and Never). The form consists of 3 subscales and 22 items: Science Checklist, Problem Solving Checklist, and Scientific Attitude Observation Inventory. The "Science Checklist" has 14 items to evaluate children's ability to make predictions and inferences, measure, define variables, interpret data, classify, observe, select graphics, and create patterns. The "Problem Solving Checklist" has 3 items to assess the skills of children to cooperate, express the problem originally, and use various solutions. In the "Scientific Attitude Observation Inventory" includes 5 items to evaluate children's trust in science activities, their flexibility, their determination, and their attitude towards science. In this study, Cronbach's alpha coefficients of the reliability were found as .94 for Science Checklist, .79 for Problem Solving Checklist, .93 for Scientific Attitude Observation Inventory and .96 for the overall scale.

\section{Data Analysis}

In the data analysis, independent samples t-test was used to determine whether the resilience levels and mathematics and science process skills of 5-year-old preschoolers differed significantly based on gender. One-way analysis of variance (ANOVA) was used to determine whether their resilience levels and mathematics and science process skills differed significantly based on variables of the number of siblings, education level of the mother and education level of the father. Kruskal-Wallis test was used to determine whether their resilience levels and mathematics and science process skills differed significantly based on family income level. Simple linear regression analysis was performed to find out to what extent children's resilience levels predicted their mathematics and science process skill levels. 


\section{RESULTS}

Findings and Comments on the First Research Question

Table 3. Results of T-Test Analysis on Resilience Levels of the 5-Year-Old Preschoolers based on Gender

\begin{tabular}{cccccccc} 
& Gender & N & $\overline{\mathbf{X}}$ & Sd & t & df & p \\
\hline Resilience & Girl & 189 & 143.37 & 26.70 & 2.552 & 382 & $.011^{*}$ \\
Level & Boy & 195 & 136.12 & 28.92 & & \\
\hline
\end{tabular}

${ }^{*} \mathrm{p}<.05$

When the analysis results in the table were analyzed, a significant difference was found $[t(382)=2.552, p=.011]$ between the resilience levels of the children in terms of gender $(p<.05)$.

Girls' resilience scores $(\bar{X}=143.37)$ were significantly higher than those of the boys $(\bar{X}=136.12)$.

Table 4. Results of ANOVA on Resilience Levels of the 5-Year-Old Preschoolers based on the Number of Siblings

\begin{tabular}{|c|c|c|c|c|c|c|c|c|}
\hline & Number of siblings & $\mathbf{N}$ & $\overline{\mathbf{X}}$ & Sd & df & $\mathbf{F}$ & $\mathrm{p}$ & Difference \\
\hline \multirow{5}{*}{$\begin{array}{l}\text { Resilience } \\
\text { Level }\end{array}$} & 1) Single child & 54 & 138.90 & 28.28 & 3 & 2.225 & .085 & \\
\hline & 2) 1 sibling & 171 & 139.63 & 27.78 & 380 & & & \\
\hline & 3) 2 siblings & 107 & 143.98 & 27.11 & 383 & & & \\
\hline & $\begin{array}{l}\text { 4) } 3 \text { or more } \\
\text { siblings }\end{array}$ & 52 & 131.84 & 29.58 & & & & \\
\hline & Total & 384 & 139.69 & 28.05 & & & & \\
\hline
\end{tabular}

When the analysis results in the table were analyzed, it was observed that the resilience levels of the children did not show a significant difference in terms of the number of siblings $[F(3.380)=2.225 ; p>.05]$. In this context, it can be asserted that the resilience scores of 5 -yearold preschoolers were similar in terms of the number of siblings (single child, one sibling, two siblings, three or more siblings).

Table 5. Results of ANOVA on Resilience Levels of the 5-Year-Old Preschoolers According to Mother's Education Level

\begin{tabular}{llccccccc}
\hline Mother's education level & $\mathbf{N}$ & $\overline{\mathbf{X}}$ & Sd & df & $\mathbf{F}$ & $\mathbf{p}$ & Difference \\
\hline \multirow{2}{*}{$\begin{array}{l}\text { Resilience } \\
\text { Level }\end{array}$} & 1) Literate-primary school & 78 & 134.20 & 32.27 & 3 & 1.733 & .160 & \\
& 2) Secondary school & 39 & 137.69 & 24.56 & 380 & & \\
& 4) High School & 131 & 143.12 & 24.11 & 383 & & \\
& Total & 136 & 140.10 & 29.63 & & & \\
\hline
\end{tabular}


When the analysis results were examined, no statistically significant difference was determined between the resilience levels of children and their mother's education level $[F(3.380)=1.733 ; p>.05]$.

Table 6. Results of ANOVA on Resilience Levels of the 5-Year-Old Preschoolers According to Father's Education Level

\begin{tabular}{llccccccc}
\hline $\begin{array}{l}\text { Father's } \\
\text { education level }\end{array}$ & $\mathbf{N}$ & $\mathbf{X}$ & Sd & df & $\mathbf{F}$ & $\mathbf{p}$ & $\begin{array}{l}\text { Difference } \\
\text { (Scheffe) }\end{array}$ \\
\hline \multirow{2}{*}{$\begin{array}{l}\text { Resilience } \text { Literate- } \\
\text { primary school }\end{array}$} & 63 & 126.26 & 31.13 & 3 & 7.517 & $.000^{*}$ & $3>1$ \\
Level & 2) Secondary & 37 & 141.02 & 24.07 & 380 & & & $4>1$ \\
& school & 129 & 138.79 & 26.08 & 383 & & \\
& 3) High School & 155 & 145.57 & 27.49 & & & & \\
& 4) University & 384 & 139.69 & 28.05 & & & \\
\hline
\end{tabular}

${ }^{*} \mathrm{p}<.05$

When the analysis results were examined, a statistically significant difference was observed between the resilience levels of the children and the education level of their fathers $[F(3.380)=7.517 ; p<.05]$. In the Scheffe post-hoc test made to find out which group caused the difference, the resilience levels of the children of fathers with high school education $(\bar{X}=138.79)$ were significantly higher than the children whose fathers were literate-primary school graduate $(\bar{X}=126.26)(p<.05)$. However, the resilience levels of the children of university graduate fathers $(\bar{X}=145.57)$ were significantly higher compared to children whose fathers were literate-primary school graduates $(\bar{X}=126.26)(p<.05)$.

Table 7. Results of Kruskal-Wallis Test on Resilience Levels of the 5-Year-Old Preschoolers According to Family Income Level

\begin{tabular}{llcccccc}
\hline & Family income level & N & Mean Rank & df & $\chi 2$ & p & Difference \\
\hline 1) Very high & 15 & 180.63 & 4 & 26.493 & $.000^{*}$ & $2-3,2-4$ \\
2) High & 141 & 221.97 & & & & $2-5,3-4$ \\
Resilience Level & 3) Medium & 137 & 193.18 & & & & $3-5$ \\
& 4) Low & 77 & 154.02 & & & & \\
& 5) Very low & 14 & 113.39 & & & & \\
Total & 384 & & & & & \\
\hline
\end{tabular}

$* \bar{p}<.05$

When the test results in the table were analyzed, the resilience levels of the 5 -year-old preschoolers differed significantly based on their family income level $\left[\chi_{2} \quad(d f=4\right.$, $n=384)=26.493 ; p<.05]$. As a result of multiple comparisons made with the Mann-Whitney $U$ test to determine the difference between which groups; the resilience levels of the children with high family income were significantly higher than those with medium-low, and very low family income $(p<.05)$. Nevertheless, the resilience levels of children with medium family income were significantly higher compared to those with low and very low family income. 
Findings and Comments on the Second Research Question

Table 8. Results of T-Test Analysis on Math Skills of the 5-Year-Old Preschoolers based on Gender

\begin{tabular}{lccccccc}
\hline & Gender & $\mathbf{N}$ & $\overline{\mathbf{X}}$ & $\mathbf{S d}$ & $\mathbf{t}$ & $\mathbf{d f}$ & $\mathbf{p}$ \\
\hline \multirow{2}{*}{ Math Skills } & Girl & 189 & 109.70 & 20.98 & -.139 & 382 & .889 \\
\hline
\end{tabular}

When the analysis results were examined, it was found that there was no significant difference between the math skill scores of the children and gender [ $\mathrm{t}(382)=.139, \mathrm{p}=.889]$ $\mathrm{p}>.05$.

Table 9. Results of ANOVA Test Analysis on Math Skills of the 5-Year-Old Preschoolers based on Number of Siblings

\begin{tabular}{llccccccc}
\hline & Number of Siblings & $\mathbf{N}$ & $\overline{\mathbf{X}}$ & Sd & $\mathbf{d f}$ & $\mathbf{F}$ & $\mathbf{p}$ & $\begin{array}{c}\text { Difference } \\
\text { (Scheffe) }\end{array}$ \\
\hline \multirow{3}{*}{ Math } & 1) Single child & 54 & 110.25 & 20.39 & 3 & 6.748 & $.000 *$ & $1>4$ \\
Skills 1 sibling & 171 & 112.09 & 20.22 & 380 & & & $2>4$ \\
& 3) 2 siblings & 107 & 111.76 & 19.62 & 383 & & & $3>4$ \\
& 4) 3 or more siblings & 52 & 98.13 & 22.26 & & & & \\
& Total & 384 & 109.85 & 28.05 & & & & \\
\hline
\end{tabular}

${ }^{*} \mathrm{p}<.05$

When the analysis results were analyzed, it was observed that the math skill scores of the children differed significantly based on the number of siblings $[F(3.380)=6.748 ; p<.05]$. In the Scheffe post-hoc test made to find out which group caused the difference, the children, who were a single child $(\bar{X}=110.25)$, had 1 sibling $(\bar{X}=112.09)$ and had 2 siblings $(\bar{X}=111.76)$, had significantly higher math skill scores than those with 3 or more siblings $(\bar{X}=98.13)$ at the level of $\mathrm{p}<.05$.

Table 10. Results of ANOVA on Math Skills of the 5-Year-Old Preschoolers According to Mother's Education Level

\begin{tabular}{llccccccc}
\hline & $\begin{array}{l}\text { Mother's } \\
\text { education level }\end{array}$ & $\mathbf{N}$ & $\overline{\mathbf{X}}$ & Sd & df & $\mathbf{F}$ & $\mathbf{p}$ & $\begin{array}{l}\text { Difference } \\
\text { (Scheffe) }\end{array}$ \\
\hline \multirow{2}{*}{ Math } & 1) Literate-primary & 78 & 101.98 & 21.99 & 3 & 6.533 & $.000^{*}$ & $3>1$ \\
school & 2) Secondary & 39 & 106.12 & 17.29 & 380 & & & $4>1$ \\
Skills & School & 131 & 111.14 & 19.11 & 383 & & & \\
& 3) High school & 136 & 114.19 & 21.39 & & & & \\
& 4) University & 384 & 109.85 & 20.82 & & & & \\
Total & & & & &
\end{tabular}

${ }^{*} \mathrm{p}<.05$

When the analysis results were examined, a statistically significant difference was observed between the math skill scores of the children and their mother's education level $[F(3.380)=6.533 ; p<.05]$. In the Scheffe post-hoc test made to find out which group caused the difference, the math skill scores of the children of high school graduate mothers $(\bar{X}=111.14$ ) were significantly higher than those of the children whose mother was the literate-primary school graduate $(\bar{X}=101.98)(p<.05)$. On the other hand, the math skill scores of the children 
of university graduate mothers $(\bar{X}=114.19)$ were significantly higher than those of the children of literate-primary school graduate mothers $(\bar{X}=101.98)(p<.05)$.

Table 11. Results of ANOVA on Math Skills of the 5-Year-Old Preschoolers According to Father's Educational Status

\begin{tabular}{llccccccc}
\hline & $\begin{array}{l}\text { Father's } \\
\text { Educational Status }\end{array}$ & $\mathbf{N}$ & $\mathbf{X}$ & Sd & df & $\mathbf{F}$ & $\mathbf{p}$ & $\begin{array}{c}\text { Difference } \\
\text { Scheffe }\end{array}$ \\
\hline \multirow{3}{*}{ Math } & 1) Literate-primary & 63 & 95.69 & 20.40 & 3 & 20.857 & $.000^{*}$ & $2>1$ \\
Skills & 2) Secol & 37 & 108.51 & 20.61 & 380 & & & $3>1$ \\
& 3) High school & 129 & 107.47 & 20.09 & 383 & & & $4>1$ \\
& 4) University & 155 & 117.90 & 17.98 & & & & $4>3$ \\
& Total & 384 & 109.85 & 20.82 & & & & \\
\hline
\end{tabular}

${ }^{*} \mathrm{p}<.05$

When the analysis results were examined, a statistically significant difference was determined between the math skill scores of the children and their father's education level $F(3.380)=20.857 ; p<.05]$. In the Scheffe post-hoc test made to find out which groups caused the difference, the math skill scores of the children, whose fathers were university $(\bar{X}=117.90)$, high school ( $\bar{X}=107.47)$ and secondary school $(\bar{X}=108.51)$ graduates, were significantly higher compared to the children whose father was literacy-primary school graduate $(\bar{X}=95.69)$. However, the math skill scores of children of university graduate fathers $(\bar{X}=117.90)$ were significantly higher than those of children of high school graduate fathers $(\bar{X}=107.47)(p<.05)$.

Table 12. Results of Kruskal-Wallis Test Analysis on Math Skills of the 5-Year-Old Preschoolers According to Family Income Status

\begin{tabular}{llcccccc}
\hline \multicolumn{1}{c}{ Family Income Level } & N & Mean Rank & df & X2 & P & Difference \\
\hline \multirow{4}{*}{ Math Skills } & 15 & 254.87 & 4 & 73.355 & $.000^{*}$ & $1-3,1-4$ \\
& 1) Very high & 141 & 240.92 & & & & $2-3,2-4$ \\
& 2) High & 137 & 184.81 & & & & $2-5,3-4$ \\
& 3) Medium & 77 & 123.54 & & & & $3-5$ \\
& 4) Low & 14 & 92.54 & & & & \\
5) Very low & 384 & & & & & \\
\hline
\end{tabular}

${ }^{*} p<.05$

When the analysis results were examined, the math skill scores of the 5 -year-old children differed significantly based on their family income level $[\chi 2(d f=4, n=384)=73.355 ; p<.05]$. As a result of multiple comparisons made with the Mann-Whitney $U$ test to determine which groups causing the difference, the math skill scores of the children with high family income were significantly higher than those of the children with "medium", "low" and "very low" family income levels. The math skill scores of the children with "very high" family income were significantly higher compared to those with "medium" and "low" family income level $(p<.05)$. However, the math skill scores of the children with "medium" family income levels were significantly higher than those of the children with "low" and "very low" family income levels. 
Findings and Comments on the Third Research Question

Table 13. Results of T-Test Analysis on Science Process Skills of the 5-Year-Old Preschoolers based on Gender

\begin{tabular}{cccccccc} 
& Gender & N & $\overline{\mathbf{X}}$ & Sd & t & df & p \\
\hline \multirow{2}{*}{ Science process skills } & Girl & 189 & 52.54 & 10.77 & \multirow{2}{*}{1.607} & \multirow{2}{*}{382} & \multirow{2}{*}{.109} \\
\hline
\end{tabular}

When the analysis results were analyzed, it was found that there was no significant difference between the gender and science process skill scores of the 5 -year-old preschoolers $[\mathrm{t}(382)=1.607, \mathrm{p}=.109]$

Table 14. Results of ANOVA on Science Process Skills of the 5-Year-Old Preschoolers According to Number of Siblings

\begin{tabular}{clccccccc}
\hline & $\begin{array}{l}\text { Number of } \\
\text { siblings }\end{array}$ & $\mathbf{N}$ & $\overline{\mathbf{X}}$ & $\mathbf{S d}$ & $\mathbf{d f}$ & $\mathbf{F}$ & $\mathbf{p}$ & $\begin{array}{c}\text { Difference } \\
\text { (Scheffe) }\end{array}$ \\
\hline \multirow{3}{*}{$\begin{array}{l}\text { Science } \\
\text { process }\end{array}$} & 1) Single child & 54 & 52.96 & 9.36 & 3 & 3.850 & $.010^{*}$ & $3>4$ \\
skills & 2) sibling & 171 & 51.43 & 10.06 & 380 & & & \\
& 3) 3 siblings & 107 & 53.35 & 9.73 & 383 & & & \\
& siblings & 52 & 47.76 & 12.03 & & & & \\
& Total & 384 & 51.69 & 10.28 & & & & \\
\hline
\end{tabular}

${ }^{*} p<.05$

When the analysis results were analysed, it was determined that the science process skill scores of the children differed significantly based on the number of siblings $[F(3,380)=3.850$; $\mathrm{p}<.05]$. In the Scheffe post-hoc test made to find out which group caused the difference, science process skill scores of the children with 2 siblings $(\bar{X}=53.35)$ were significantly higher than those of children with 3 siblings $(\bar{X}=47.76)(p<.05)$.

Table 15. Results of ANOVA on Science Process Skills of the 5-Year-Old Preschoolers According to Mother's Education Level

\begin{tabular}{clccccccc} 
& Mother's education level & N & $\overline{\mathbf{X}}$ & Sd & df & $\mathbf{F}$ & $\mathbf{p}$ & Difference \\
& & & & & & & & \\
\hline \multirow{2}{*}{ Science } & 1) Literate-primary school & 78 & 48.98 & 11.97 & 3 & 2.355 & .072 & \\
process & 2) Secondary School & 39 & 52.12 & 8.73 & 380 & & & \\
skills & 3) High School & 131 & 52.38 & 9.20 & 383 & & \\
& 4) University & 136 & 52.46 & 10.46 & & & & \\
& Total & 384 & 51.69 & 10.28 & & & & \\
\hline
\end{tabular}

When the analysis results were examined, it was determined that there was no statistically significant difference between the science process skill scores of the children and their mother's education levels $[F(3.380)=2.355 ; p>05]$.

Table 16. Results of ANOVA on Science Process Skills of the 5-Year-Old Preschoolers According to Father's Education Level

\begin{tabular}{clccccccc}
\hline & $\begin{array}{c}\text { Father's } \\
\text { Education Level }\end{array}$ & N & $\overline{\mathbf{X}}$ & Sd & df & F & p & $\begin{array}{c}\text { Difference } \\
\text { Scheffe }\end{array}$ \\
\hline $\begin{array}{c}\text { Science } \\
\text { process skills }\end{array}$ & $\begin{array}{l}\text { 1) Literate- } \\
\text { primary school }\end{array}$ & 78 & 44.98 & 10.99 & 3 & 14.389 & $.000^{*}$ & $2>1$
\end{tabular}




$\begin{array}{lccccc}\text { 2) Secondary } & 39 & 52.75 & 9.61 & 380 & 3>1 \\ \text { School } & & 51.27 & 9.51 & 383 & 4>1 \\ \text { 3) High School } & 131 & 54.50 & 9.51 & & \\ \text { 4) University } & 136 & 54.51 & \\ \text { Total } & 384 & 51.69 & 10.28 & & \end{array}$

${ }^{*} p<.05$

When the analysis results were analyzed, a statistically significant difference was determined between the science process skill scores of the children and their fathers' education level $[F(3.380)=14.389 ; p<.05]$. In the Scheffe post-hoc test made to find out which group caused the difference, science process skill scores of the children, whose fathers were university $(\bar{X}=54.50)$, high school $(\bar{X}=51.27)$, and secondary school $(\bar{X}=52.75)$ graduate, were significantly higher than those of the children of literacy-primary school graduate fathers $(\bar{X}=44 \cdot 98)$.

Table 17. Results of Kruskal-Wallis Test Analysis on Science Process Skills of the 5-Year-Old Preschoolers According to Family Income Level

\begin{tabular}{cllccccc}
\hline & \multicolumn{1}{c}{$\begin{array}{c}\text { Family income } \\
\text { level }\end{array}$} & $\mathbf{N}$ & $\begin{array}{c}\text { Mean } \\
\text { Rank }\end{array}$ & df & $\chi^{2}$ & p & Difference \\
\hline & 1) Very high & 15 & 234.00 & 4 & 43.030 & $.000 *$ & $1-4,1-5$ \\
& 2) High & 141 & 230.84 & & & $2-3,2-4$ \\
Science process & 3) Medium & 137 & 185.74 & & $2-5,3-4$ \\
skills & 4) Low & 77 & 139.17 & & $3-5$ \\
& 5) Very low & 14 & 121.32 & & & \\
\hline
\end{tabular}

${ }^{*} \mathrm{p}<.05$

Findings and Comments on the Fourth Research Question

Table 18. Analysis Results Regarding the Correlation between the Resilience Levels and Math Skills of the 5Year-Old Preschoolers

\begin{tabular}{lcc}
\hline Variable & Resilience & Math Skills \\
\hline Resilience & - & $.667^{* *}$ \\
Math Skills & $.667^{* *}$ & - \\
\hline
\end{tabular}

$* * p<.01$

When the analysis results in the table were examined, it was observed that there was a positive and moderate significant correlation between the resilience levels and mathematical skills of the 5 -year-old children $(r=.667 ; p<0.01)$.

Findings and Comments on the Fifth Research Question

Table 19. Analysis Results Regarding the Correlation between the Resilience Levels and Science Process Skills of the 5-Year-Old Preschoolers

\begin{tabular}{lcc}
\hline Variable & Resilience & Science process skills \\
\hline Resilience & - & $.756^{* *}$ \\
Science process skills & $.756^{* *}$ & - \\
\hline$* *$ & &
\end{tabular}


When the analysis results were analyzed, it was determined that there was a positive and highly significant correlation between the resilience levels and science process skills of the 5year-old preschoolers $(r=.756 ; p<0.01)$.

Findings and Comments on the Sixth Research Question

Table 20. Results of Simple Linear Regression Analysis Regarding Prediction of Mathematical Skills of the 5Year-Old Preschoolers

\begin{tabular}{lccccc}
\hline Variable & B & Standard Error & $\boldsymbol{\beta}$ & $\mathbf{T}$ & $\mathbf{p}$ \\
\hline Constant & 40.659 & 4.030 & & 10.088 & .000 \\
Resilience & .495 & .028 & .667 & 17.510 & .000 \\
\hline
\end{tabular}

$R=.667, R^{2}=.445 F(1-383)=306.600 P=.000$

In the analysis, while resilience was considered as an independent (predictive) variable, math skills were considered as a dependent (predicted) variable. When the simple linear regression results in the table were evaluated, resilience levels of the children were observed to be a significant predictor of their mathematical skills $\left[R=.667, R^{2}=.445, p=.00\right]$. According to these results, the resilience levels of the children accounted for $44.5 \%$ of the total variance related to the scores of the mathematics education content standards scale.

Table 21. Results of Simple Linear Regression Analysis Regarding Prediction of Science Process Skills of the 5Year-Old Preschoolers

\begin{tabular}{lccccc}
\hline Variable & B & Standard error & $\boldsymbol{\beta}$ & $\mathbf{T}$ & $\mathbf{P}$ \\
\hline Constant & 12.992 & 1.749 & & 7.426 & .000 \\
Resilience & .277 & .012 & .756 & 22.562 & .000 \\
\hline
\end{tabular}

$R=.756, R^{2}=.571 F(1-383)=509.029 P=.000$

In the analysis, while resilience was considered as an independent (predictive) variable, science process skills were considered as dependent (predicted) variables. When the simple linear regression results in the table were evaluated, resilience levels of the children were a significant predictor of their science process skills $\left[R=.756, R^{2}=.571, p=.00\right]$. According to these results, the resilience levels of the children accounted for $57.1 \%$ of the total variance related to the scores of the science processes observation form.

\section{DISCUSSION AND CONCLUSION}

In this section, the resilience levels and mathematics and science process skills of the 5-yearold preschoolers and whether these skill levels varied based on gender, mother's education level, father's education level, number of siblings and family income level, as well as the correlations between them, were examined and discussed in accordance with the research questions examined in the study.

\section{Results for the First Research Question}

The resilience levels of 5-year-old preschoolers showed a significant difference in favor of girls in terms of the scores of the Early Childhood Resilience Scale. This may be associated with the fact that girls' social-emotional skills may be more advanced than boys in life difficulties and stressful situations. While girls generally use more social support, positive thoughts and social strategies in coping with stress, boys tend towards physical activities (Frydenberg \& Lewis, 
1993). Additionally, Hampel and Petermann (2005) investigated the effect of gender on coping skills of children and adolescents in their study and observed that girls obtained high scores in their ability to cope with difficulty in seeking support and incompatible conditions (a dimension of resilience). Werner (1993) states that especially girls have better cognitive and reading skills and are more resilient than children who develop problems later. While there are similar study findings in the literature (Erdem, 2017; Gundas \& Kocak, 2015; Onat, 2010; Sun \& Stewart, 2007), some studies have reported that resilience levels do not cause a significant difference in terms of gender (Ciftci Aridag \& Unsal Seydoogullari, 2018; Erkoc, 2019). However, in some studies (Bahadir Yilmaz \& Oz, 2015; Lazaridou \& Beka, 2014), the resilience levels of boys were found to be higher than girls. Different findings in the literature may have been caused by the characteristics of the sample or study group, or whether risk factors are taken into consideration in determining individuals included in the sample in resilience studies. The presence of risk factors is essential for the development of resilience. For this reason, it is thought that the studies conducted without risk factors would not meet the theoretical framework of resilience (Isik, 2016).

It was observed that the resilience levels of the 5-year-old children who attended preschool education did not make a significant difference according to the number of siblings. In other words, the resilience scores of the children were similar in terms of the number of siblings. This result can be explained by the fact that resilience depends mostly on individual characteristics and intrinsic motivation. In this context, when resilience is considered as a process of adaptation, it means successfully fulfillment of the most obvious individual tasks for the developmental periods (Egeland, Carlson \& Sroufe, 1993). In the study by Terzi (2000), the students' scores on interpersonal problem-solving skill perceptions, which are a dimension of resilience, did not constitute a difference according to the number of siblings, which supports the present study. On the other hand, in the study by Erdem (2017), it was found that the number of children in the family did not lead to differentiation in resilience levels.

There was no statistically significant difference between the resilience levels of the 5-year-old preschoolers and their mother's education level. This finding may be associated with the fact that mother is generally more responsible for raising children than father according to traditions of Turkish society and differences such as education level or working status of mother do not change the mother's way of raising the child. In this case, the resilience of the child may affect the father or other family members other than the mother. In the study by Ogelman (2015), she determined that fathers had more effect on the resilience levels of children when compared to mothers. The study conducted by Erdem (2017) with preschool children revealed that the resilience levels of the children did not change according to the education level of the mother, which supports the finding of the study. Contrary to these findings in the literature, Bahadir Yilmaz and Oz (2015) stated that as the education level of the parents decreased, the resilience level of students increased, that is, an inverse proportion between the of parental education level and the resilience of the children.

There was a statistically significant difference between the resilience levels of the participants and their fathers' education level. This difference was in favor of those with high educational status probably due to the fact that as the education level increases, parental attitudes become more democratic, and parents' social-emotional development such as getting help, communication, empathy, and protective relationships are supported more by parents. While authoritarian parents prevent the child from gaining experience due to their strict discipline and punishment (Eldeleklioglu, 1996), democratic parents create the most positive 
environment for their children 's identity and personality development with unconditional love and respect (Ciftci Aridag \& Unsal Seydoogullari, 2018). In the study conducted by Ogelman (2015), to examine the predictive effect of parents' acceptance-rejection levels on the resilience of their preschool children, a negative and strong correlation was found between the neglect/indifference and aggression/hostility levels of the fathers and the resilience levels of the children. In the study by Erdem (2017), the resilience levels of children of high school graduate fathers were higher than those of children of primary school graduate fathers. In their study, Arastaman and Balci (2013) showed that there was a significant correlation between student resilience and family support and family support was an important determinant of student resilience. If parents are successful in providing an emotionally stable and stimulating environment, the negative effects of material restraints can be minimized.

The resilience levels of the 5-year-old children showed a significant difference according to their family income. This difference was in favor of those with higher family income. Newbigging (2018) defines resilience as the ability to handle life's difficulties and stress in a healthy and positive way. Social and economic conditions affect a child's ability to develop resilience. Huang, Han, Sun, Zhang, \& Li (2018) state that low socioeconomic family status is closely related to increased risk of emotional adjustment and resilience among adolescents. Terzi (2000) observed that the highest mean scores of interpersonal problem-solving skill levels, a dimension of resilience, were determined in students from the upper socioeconomic level, which was followed by students from the medium and lower socioeconomic levels, respectively.

\section{Results for the Second Research Question}

There was no significant difference between the gender and mathematical skill scores of 5year-old preschoolers. This may be due to the fact that the differences in the academic success of children in the preschool period were not yet clear in terms of gender, and the perspective of children on mathematics and the activities in the context of gender in this period is not completely different. As a matter of fact, in their study, Leahey and Guo (2001) examined the gender differences in mathematics level and determined that the average reasoning scores of girls between the ages of 11-13 were statistically significant and higher when there was a minor gender difference in the field of mathematical reasoning. In the literature, similar results were found in studies examining the correlation and difference between children's mathematical skills and gender (Avcilar \& Kesicioglu, 2018; Avci, 2015; Aktas Arnas, Deretarla Gul \& Sigirtmac, 2003; Bulut Peduk, 2007; Ceylan, 2016; Celik, 2015; Dagli, 2007; Demir \& Dere Ciftci, 2018; Karaman, 2012; Kuru, 2015; Polat Unutkan, 2007; Sezer, 2008; Taskin, 2013).

It was found that mathematical skill scores of the 5-year-old children who attended preschool education differed significantly according to the number of siblings. Mathematical skill scores of the children who were a single child or had 1 sibling and 2 siblings were significantly higher compared to the children with 3 or more siblings. This finding may be due to the fact that as the number of siblings increases, the time allocated by parents for each child may be shorter and the available socioeconomic opportunities may be more limited. The lower or higher number of siblings affects the success level of the children (Saral, 1993). In a study, the success scores of the children who had two siblings at most were found to be higher than those with many siblings (Saral, 1993). In the study by Avci (2015), the math talent score 
varied based on the number of children in the family, the children of families having 2 children had the highest mean score, which was followed by children of families with one child, 4 and 3 children. There are also studies in the literature reporting no significant difference between the number of siblings and success (Aslanargun, Bozkurt \& Sarioglu, 2016; Guven, 2007; Sezer, 2008). These differences may have resulted from the characteristics of the sample group determined based on a criterion.

A statistically significant difference was found between the mathematical skill scores of 5year-old preschoolers and their mother's education level. This difference was in favor of the children of mothers with a higher education level. This finding is associated with the fact that the mother with higher education level can have more knowledge, skills, and concepts related to other academic skills, especially mathematics in the preschool period, and they can direct their children accordingly and increase the number and variety of activities related to mathematics at home. In this context, Musun Miller and Blevins Knabe (1998) stated that as parents attached more importance to mathematics, they performed more mathematical activities with their children. They also stated that high levels of parental involvement in mathematics were closely related to the development and support of all skill areas. Similar studies in the literature (Aslanargun et al., 2016; Bulut Peduk, 2007; Celik, 2015; Dagli, 2007; Guven, 2007; Karabekmez, 2018; Lopez, Gallimore, Garnier, \& Reese, 2007; Ozer \& Anil, 2011) support this finding.

There was a statistically significant difference between the mathematical skill scores of the 5year-old preschoolers and their fathers' education level. This difference was in favor of the children of fathers with higher education levels. This finding may be associated with the fact that the education level of fathers is a measure of the cognitive support they will provide to their children because the child-rearing starts mainly in the family and the family is the primary factor in the acquisition of mathematics and other academic skills during the preschool period. Furthermore, in their study, Musun Miller and Blevins Knabe (1998) stated that parents and teachers are more effective than the child's innate skills, and especially parents had the greatest impact on all development areas of preschool children. In her study, Peters (1998) reported that games were effective in increasing children's learning in order to support and spread their mathematical learning only if there was parental support. Some studies in the literature (Aslanargun et al., 2016; Celik, 2015; Guven, 2007; Lopez et al., 2007; Ozer \& Anil, 2011) support this finding.

Mathematical skill scores of the 5-year-old preschoolers differed significantly based on their family income. This difference was in favor of those with higher family income levels in each group. This finding may be due to the fact that the increase in family income level supports mathematical learning of the children, various environments and functional materials can be found more at home, and this provides an important contribution to the formation of prelearning about children and reinforcing what is learned. Anderson (1997) states that children's mathematical learning can be supported in contextualized ways with concrete materials and pictures so that the acquisition of mathematical skills can be more effective. However, Sakakibara (2014) emphasizes that mathematical knowledge of students at risk (for example, students from low-income families) is lower than those without risk, even when starting school. Children from low-income families are more likely to have poor mental experiences compared to children from high-income families (Newbigging, 2018). In the literature, there are studies supporting the results of the present study (Aslanargun et al., 2016; Celik, 2015; Starkey, Klein \& Wakeley, 2004; Zheng \& Libertus, 2018). 
Results for the Third Research Question

There was no significant difference between the gender and the science process skill scores of the 5-year-old preschoolers. This finding may be associated with the fact that preschool-aged children do not yet have differentiation in their science activities according to their gender, they discover something new every day during the process of recognizing and understanding the nature, they use basic processes in these discovery experiences and they are inadequate to experience all these. In this context, secondary school years after early childhood are expressed as a period when differences in success generally increase based on gender (Jones, Howe \& Rua, 2000). In their study, Guo, Piasta, and Bowles (2015) examined science knowledge of preschool children from various contexts and found that their ability to understand the concepts of science during preschool years was the same for girls and boys. Some studies in the literature support the results of the present study (Akman, Ustun \& Guler, 2003; Kunt, Ozel \& Kunt, 2015; Kesik, 2016; Kuru \& Akman, 2017; Olcer, 2017; Ramazan \& Demir; 2011).

It was found that the science process skill scores of the 5-year-old preschoolers differed significantly according to the number of siblings. This difference was found to be significantly higher in children with 2 siblings than those with 3 or more siblings. This result may be due to the fact that parents with a high number of children can allocate more limited financial/moral opportunities for each child. The number of siblings affects the success level of children (Saral, 1993). In the study, the success scores of the children with two siblings were found to be higher than those with more siblings (Saral, 1993). The results of the study by Kilic and Hasiloglu (2017) revealed that as the number of siblings increased, the academic success rates of the students in Turkish and Science decreased. In the study conducted by Olcer (2017) to examine the science content knowledge in preschool children aged 5-6 years, it was observed that the scores of the children in the physical sciences, life sciences, earth and space sciences subscales were in favor of single child in terms of the number of siblings.

There was no statistically significant difference between the science process skill scores of the 5-year-old children and their mothers' education level. The results of the study conducted by Kilic and Hasiloglu (2017) indicated that there was no significant difference between the mother's education level and the students' success in science class, which supports this result of the present study. In the literature, there are also studies not supporting this result (Guo et al., 2015; Olcer, 2017; Ramazan \& Demir, 2011). Different results in the literature may have been associated with the characteristics of the sample or study group or whether risk factors are taken into consideration in determining individuals included in the sample in resilience studies. There was a statistically significant difference between the science process skill scores of the 5-year-old preschoolers and their fathers' education level. This difference was in favor of the children of fathers with higher education levels. This is thought to be directly related to the patriarchal Turkish family structure, thus, the fathers' position in the family and their role in child-rearing. For this reason, the education level of the father has an important effect on the academic success of the children. In the literature, there are studies supporting the result of the present study related to parental education levels (Burusic, Simunović \& Velic, 2018; Kesik, 2016; Kunt et al., 2015; Olcer, 2017; Ozer \& Anil, 2011).

Science process skill scores of the 5-year-old preschoolers differed significantly based on their family income level. This difference was in favor of those with higher family income levels. This result may be due to the fact that as family income level increases the child could experience 
richer learning experiences. Children from low-income families are more likely to have poor mental experiences compared to children from high-income families (Newbigging, 2018). In their study, Burusić et al., (2018) stated that students with low socioeconomic levels had lower success in STEM and there was a positive correlation between family income and children's STEM success. In the study conducted by Davis Kean (2005) to investigate the effect of parental education and family income on a child's success, it was found that parental education and family income caused significant differences in the academic success of children. In their study, Gutman and Eccles (1999) found that the financial strain of the parents likely increased the presence of negative parent-adolescent relationships and affected negatively the parental involvement at school.

\section{Results for the Fourth Research Question}

It was observed that there was a positive and moderate significant correlation between the resilience levels and mathematical skills of the 5-year-old preschoolers. Difficulties and obstacles in the learning process of mathematics can lead to unwanted pressures and adverse conditions. These negative pressures and conditions can result in negative learning experiences for students. In this context, resilience enables students to deal with and overcome obstacles and negative situations in the learning process so that they can turn these negative situations into positive ones. In this respect, flexible students can achieve better learning success in the learning process (Hutauruk \& Priatna, 2017). Children's cognitive abilities affect problem-solving and other adaptation aspects (Masten, Best \& Garmezy, 1990). When considering that resilience is a psychomotor adaptation process (Masten \& Powell, 2003), it can be asserted that the child's adaptation processes and math skills are interactive. In the resilience study conducted by Cutuli et al., (2012) with students at risk, they found that the negative life events affected and increased the mathematics achievement of low-income students. Resilient learners know that learning math requires struggle and they can find appropriate support and experience positive emotions related to success. In this respect, teaching mathematical resistance allows students to use math skills effectively and gain new math skills when necessary (Lee \& Johnston Wilder, 2017).

\section{Results for the Fifth Research Question}

It was observed that there was a positive and high correlation between resilience levels and the science process skills of the 5-year-old preschoolers. In other words, any increase/decrease in resilience levels of the children increased/decreased science process skills. Science process skills refer to the ways to access and use information. Scientists observe, group, compare, measure, experiment, create hypotheses, make decisions, and try to draw conclusions. Just like scientists, children engage in these activities at early ages. This is inherent in children (Tan \& Temiz, 2003). Along with their inherent science process activities, children have innate resilience characteristics. In this context, innate resilience capacity helps children develop critical awareness and focus on a goal and problem-solving skills (Benard, 1995). Also, resilient children tend to establish positive communication and relationships with the family, school, and community (Benard, 1993). It can be asserted that communication skills can be high in science process skills. The fact that children are strong and resilient to the difficulties in science learning along with academic success also makes it indispensable. Some countries, communities, and individuals are considered to be more resilient than others. The data obtained from PISA revealed that when approximately $25 \%$ (one million) of disadvantaged students in OECD counties were compared with students in other countries, 
they were more resilient and had a higher level of basic skills such as mathematics, science, and reading (OECD, 2014). In the study by Mwangi, Okatcha, Kinai, and Ireri (2015) to examine the relationship between academic resilience and achievement, they found a positive and significant correlation. This study revealed that academically resistant students were more successful at school.

\section{Results Regarding the Sixth Research Question}

It was observed that the resilience levels of the 5-year-old preschoolers were a significant predictor of their mathematical skills. According to these results, their resilience levels accounted for $44.5 \%$ of the total variance related to their scores of the mathematics education content standards scale. In addition, it was observed that the resilience levels of children were a significant predictor of science process skill levels. According to these results, their resilience levels accounted for $57.1 \%$ of the total variance related to their scores of the science processes observation form. These results showed that the resilience levels of preschool children were a significant predictor of their early academic skills. This effect predicts children to be successful in early academic skills by adapting to all negativities in the face of challenging conditions in life, negative experiences, and academic difficulties. In this context, it was observed that children's social/emotional/behavioral skills were a significant predictor of their cognitive skills.

\section{Recommendations}

The results of the present study revealed that children's resilience level was a significant predictor of early academic skills such as math and science process skills. In this context, considering that all development areas affect and complement each other and development as a whole, educators in schools can provide special contributions to multi-faceted development by supporting them in their social, behavioral, and affective characteristics without focusing only on academic success/skill. In this study conducted on resilience levels and mathematics and science process skills of the 5-year-old children, the gender, parental education level, the number of siblings, and family income level were limited to quantitative data obtained from the relevant scales. In this context, it is recommended to acquire new gains to support child development with different findings related to resilience, mathematics and science process skills by using mixed methods and various demographic variables including different preschool age groups.

\section{REFERENCES}

Abasli, K., \& Polat, S. (2019). Duygusal ozerklik ve ogrenci yilmazligi arasindaki iliskilerin ogrenci goruslerine gore incelenmesi. Gazi Egitim Bilimleri Dergisi (GEBD), 5(1), 1-15. doi: 10.30855/gjes.2019.05.01.001.

Akman, B., Ustun, E., \& Guler, T. (2003). 6 yas cocuklarinin bilim sureclerini kullanma yetenekleri. Hacettepe Universitesi Egitim Fakultesi Dergisi, 24, 11-14. Retrieved from https://dergipark.org.tr/en/download/article-file/87823.

Aktas Arnas., Y., Deretarla Gul, E., \& Sigirtmac, A. (2003). 48-86 ay cocuklar icin sayı ve islem kavramlari testi'nin gecerlilik ve guvenirlik calısması. Cukurova Universitesi Sosyal Bilimler Enstitusu Dergisi, 12(12), 147-157. Retrieved from https://dergipark.org.tr/tr/download/article-file/50139. 
Anderson, A. (1997). Families and mathematics: a study of parent-child interactions. Journal for Research in Mathematics Education, 28(4), 484-511.

Arastaman, G., \& Balci, A. (2013). Investigation of high school students' resiliency perception in terms of some variables. Educational Sciences: Theory \& Practice, 13(2), 922-928. Retrieved from https://files.eric.ed.gov/fulltext/EJ1017335.pdf.

Aslanargun, E., Bozkurt, S., \& Sarioglu, S. (2016). Sosyo ekonomik degiskenlerin ogrencilerin akademik basarisi uzerine etkileri. Usak Universitesi Sosyal Bilimler Dergisi, 9(3), 214234.

Avci, K. (2015). Okul oncesi egitimi alan 48-66 aylik cocuklarin matematik becerilerinin bazi degiskenler acisindan incelenmesi (Master's thesis). YOK National Thesis Center is obtained from the database. (Thesis No: 381204).

Avcilar, T., \& Kesicioglu, O. S. (2018). Okul oncesi donem cocuklarin olcme becerilerinin incelenmesi. Elektronik Sosyal Bilimler Dergisi, 17(68), 1548-1569.

Bahadir Yilmaz, E., \& Oz, F. (2015). The resilience levels of first-year medical, dentistry, pharmacy and health sciences students. International Journal of Caring Sciences, 8(2). 385-392.

Benard, B. (1993). Fostering resiliency in kids. Character education. Educational Leadership,

51(3), 44-48. Retrieved from:http://www.ascd.org/publications/educational leadership/nov93/vol51/num03/Fostering-Resiliency-in-Kids.aspx retrieved on 08.08.2019.

Benard B. (1995). Fostering resilience in children. Retrieved from :https://eric.ed.gov/?id=ED386327 retrieved on 05.02.2020 .

Brackenreed, D. (2010). Resilience and risk. International Education Studies, 3(3). doi:10.5539/ies.v3n3p111.

Bulut Peduk, S. (2007). Alti yas grubundaki cocuklara coklu zeka kuramina dayali olarak verilen matematik egitiminin matematik yetenegine etkisinin incelenmesi (Doctoral dissertation). YOK National Thesis Center is obtained from the database. (Thesis No: 196491).

Burusic, J., Simunović, M., \& Velic, M. S. (2018). Parental education, family income and students stem school achievement: Research findings from Croatian primary school. Running Head: Parents and Stem- AERA 2018 Conference paper. Retrived from: https://www.researchgate.net/publication/324757037_Parental_Education_Family_In come_and_Students_STEM_School_Achievement_Research_Findings_from_Croatia n_Primary_School retrieved on 15.10.2019.

Buyukozturk, S., Kilic Cakmak, E., Akgun, O. E., Karadeniz, S. ve Demirel, F. (2012). Bilimsel arastirma yontemleri. (12. baski). Ankara: Pegem Akademi.

Celik, M. (2015). Anasinifina devam eden 60-72 aylik cocuklarin matematik gelisimlerinin bazi degiskenler acisindan incelenmesi, Dicle Universitesi Ziya Gokalp Egitim Fakultesi Dergisi, 24, 1-18. doi: 10.14582/DUZGEF.401.

Ceylan, M. (2016). Okul oncesi donemde erken matematik yetenegi duzeyleri (Master's thesis). YÖK National Thesis Center is obtained from the database. (Thesis No: 430725).

Cicchetti, D. (2010). Resilience under conditions of extreme stress: a multilevel perspective. World Psychiatry, 9(3), 145-154. doi:10.1002/j.2051-5545.2010.tbo0297.x

Ciftci Aridag, N., \& Unsal Seydoogullari, S. (2018). Lise ogrencilerinin yasam doyumu ve yilmazlik duzeylerinin anne-baba tutumlariyla iliskisi acisindan incelenmesi. Hacettepe Universitesi Egitim Fakultesi Dergisi, 34(4), 1037-1060. doi: 10.16986/HUJE.2018038527

Cohen, L., Manion, L. ve Morrison, K. (2005). Research methods in education. (5th edition). London: Routledge Falmer. 
Cutuli, J. J., Desjardins, C. D., Herbers, J. E., Long, J. D., Heistad, D., Chan, C.-K., ... Masten, A. S. (2012). Academic achievement trajectories of homeless and highly mobile students: resilience in the context of chronic and acute risk. Child Development, 84(3), 841-857.

Dagli, A. (2007). Okul oncesi egitimi alan ve almayan ilkogretim birinci sinif ogrencilerinin Turkçe ve matematik derslerindeki akademik basarilarinin karsilastirilmasi (Master's thesis). YOK National Thesis Center is obtained from the database. (Thesis No: 217492).

Davis Kean, P. E. (2005). The influence of parent education and family income on child achievement: The indirect role of parental expectations and the home environment. Journal of Family Psychology, 19(2), 294-304.

Demir, E., \& Dere Ciftci, H. (2018). 5-6 yas cocuklarina sayi kavramini kazandirmada drama calismalarinin etkisinin incelenmesi. Erken Cocukluk Calismalari Dergisi, 2(2), 309-333. doi: $10.24130 /$ eccd-jecs.196720182263.

Egeland, B., Carlson, E., \& Sroufe, L. A. (1993). Resilience as process. Development and Psychopathology, 5(04), 517-528. doi:10.1017/S0954579400006131.

Eldeleklioglu, J. (1996). Karar stratejileri ile ana-baba tutumlari arasindaki iliski. Turk Psikolojik Danısma ve Rehberlik Dergisi, 2(11), 7-13.

Erdem, E. (2017). Okul oncesi egitime devam eden 4-5 yasindaki cocuklarin yilmazlik ozellikleri ve yilmazligi destekleyici faktorlerin incelenmesi (Master's thesis). YÖK National Thesis Center is obtained from the database. (Thesis No: 461506).

Erdil, Z. (2010). Sosyoekonomik olarak risk altinda bulunan cocuklara yonelik erken mudahale programlari ve akademik basari iliskisi. Saglık Bilimleri Fakultesi Hemsirelik Dergisi, 7278.

Erkoc, N. (2019). Ilkokul yoneticilerinin yilmazlik, duygusal zeka ve yonetsel etkililik duzeyleri arasindaki iliskinin incelenmesi (Master's thesis). YÖK National Thesis Center is obtained from the database. (Thesis No: 551117 ).

Ersay, E. (2018). Erken cocukluk yilmazligi: Yeni olcekten umut veren sonuclar (Early Childhood Resilience: Promising Results from a New Scale). 70. Erken Cocukluk Egitimi Dunya Organizasyonu (OMEP) Uluslararasi Kongresi. 27 - 29 Haziran, Prag/Cek Cumhuriyeti.

Ersay, E., \& Erdem, E. (2017). Turkiye de yeni gelistirilen erken cocukluk yilmazlik olcegi (New Developed Early Childhood Resilience Scale in Turkey). 6th The European Network for Social and Emotional Competence (ENSEC) Conference, 07 - 09 Haziran, Stokholm/ISVEC.

Erturk Kara, G. (2017). Cocuklarin davranissal becerilerinin erken akademik becerilerini yordamadaki rolu. Uluslararasi Sosyal Arastirmalar Dergisi, 10(49), 432-441.

Fredricks, J. A., Blumenfeld, P. C., \& Paris, A. H. (2004). School engagement: potential of the concept, state of the evidence. Review of Educational Research, 74(1), 59109. doi:10.3102/00346543074001059.

Frydenberg, E., \& Lewis, R. (1993). Boys play sport and girls turn to others: age, gender and ethnicity as determinants of coping. Journal of Adolescence, 16(3), 253266. doi:10.1006/jado.1993.1024.

Guo, Y., Piasta, S. B., \& Bowles, R. P. (2015). Exploring preschool children's science content knowledge. Early Education and Development, 26(1), 125146. doi:10.1080/10409289.2015.968240.

Gutman, L. M., \& Eccles, J. S. (1999). Financial strain, parenting behaviors, and adolescents' achievement: testing model equivalence between African American and European American single- and two-parent families. Child Development, 70(6), 14641476. doi:10.1111/1467-8624.00106.

Gundas, A. ve Kocak, R. (2015). Lise ogrencilerinde psikolojik saglamligin yordayicisi olarak benlik kurgusu. Uluslararasi Sosyal Araştirmalar Dergisi, 8(41), 795-802. 
Gurgan, U. (2006). Grupla psikolojik danismanin universite ogrencilerinin yilmazlik duzeylerine etkisi (Doctoral dissertation). YOK National Thesis Center is obtained from the database. (Thesis No: 205194).

Guven, Y. (2007). Okuloncesi donem cocuklarinin sezgisel matematik yeteneklerinin incelenmesi. Marmara Universitesi, A.E.F. Ilkogretim Bolumu. Oneri, 7 (28), 389-395.

Hampel, P., \& Petermann, F. (2005). Age and gender effects on coping in children and adolescents. Journal of Youth and Adolescence, 34(2), 73-83. doi:10.1007/s10964-0053207-9.

Huang, S., Han, M., Sun, L., Zhang, H., \& Li, H.-J. (2018). Family socioeconomic status and emotional adaptation among rural-to-urban migrant adolescents in China: The moderating roles of adolescent's resilience and parental positive emotion. International Journal of Psychology. doi:10.1002/ijop.12499.

Hutauruk, A. J. B., \& Priatna, N. (2017). Mathematical resilience of mathematics education students. Journal of Physics: Conference Series, 895, 012067. doi:10.1088/1742$6596 / 895 / 1 / 012067$.

Isik, S. (2016). Turkiye'de kendini toparlama gucu konusunda yapilmis arastirmalarin incelenmesi. Turk Psikolojik Danisma ve Rehberlik Dergisi, 6(45), 65-76.

Jones, M. G., Howe, A., \& Rua, M. J. (2000). Gender differences in students' experiences, interests, and attitudes toward science and scientists. Science Education, 84(2), 180192.

Karabekmez, S. (2018). Okul oncesi egitimi alan 5 yas cocuklarinin sayi becerilerinin bazi degiskenler acisindan incelenmesi (Master's thesis). YOK National Thesis Center is obtained from the database. (Thesis No: 501129).

Karaman, S. (2012). Okul oncesi egitim kurumuna devam eden 6 yas cocuklarinin matematik becerileri ile sosyodramatik oyunun boyutlari arasindaki iliskinin incelenmesi (Master's thesis). YOK National Thesis Center is obtained from the database. (Thesis No: 384158).

Karasar, N. (2015). Bilimsel Arastirma Yontemi (28. basım). Ankara: Nobel Akademik Yayincilik.

Kesik, C. (2016). Ilkokul ucuncu sinif ogrencilerinin fen okuryazarligini belirlemeye yonelik envanter gelistirme ve uygulama (Sanliurfa ili ornegi) (Master's thesis). YOK National Thesis Center is obtained from the database. (Thesis No: 421594).

Kilic, Y., \& Hasiloglu, M. A. (2017). Sosyoekonomik durumun ogrenci basarisina etkisi (7. sinif Turkce ve fen bilimleri dersleri orneklemi). YYU Egitim Fakultesi Dergisi 14 (1), 10251049.

Kunt, B. Ozel, E., \& Kunt, H. (2015). 60-72 ay okul oncesi ogrencilerinin bilimsel surec becerilerinin belirlenmesi. Eurasian Education \& Literature Journal, 3, 41-55.

Kuru, N. (2015). 48-66 aylik cocuklarin bilimsel surec becerileri ve matematik kavramlari arasindaki iliskinin incelenmesi (Master's thesis). YOK National Thesis Center is obtained from the database. (Thesis No: 394844).

Kuru, N., \& Akman, B. (2017). Okul oncesi donem cocuklarinin bilimsel surec becerilerinin ogretmen ve cocuk degiskenleri acisindan incelenmesi. Egitim ve Bilim, 42(190), 269279. Retrieved from http://egitimvebilim.ted.org.tr/index.php/EB/article/view/6433.

Lazaridou, A., \& Beka, A. (2014). Personality and resilience characteristics of Greek primary school principals. Educational Management Administration \& Leadership, 1-20. doi:10.1177/1741143214535746.

Leahey, E., \& Guo, G. (2001). Gender differences in mathematical trajectories. Social Forces, 80(2), 713-732. doi:10.1353/sof.2001.0102. 
Lee, C., \& Johnston Wilder, S. (2017). The construct of mathematical resilience. (Chapter 10). Understanding emotions in mathematical thinking and learning, 269-291. doi:10.1016/B978-0-12-802218-4.00010-8.

Lopez, E. M., Gallimore, R., Garnier, H., \& Reese, L. (2007). Preschool antecedents of mathematics achievement of latinos. Hispanic Journal of Behavioral Sciences, 29(4), 456-471. doi:10.1177/0739986307305910.

Luthar, S. S., \& Cicchetti, D. (2000). The construct of resilience: Implications for interventions and social policies. Development and Psychopathology, 12(4), 857885. doi:10.1017/S0954579400004156.

Masten, A. S., Best, K. M., \& Garmezy, N. (1990). Resilience and development: Contributions from the study of children who overcome adversity. Development and Psychopathology, 2(04), 425-444. doi:10.1017/S0954579400005812

Masten, A. S., \& Cicchetti, D. (2016). Resilience in development: progress and transformation. Developmental Psychopathology, 1-63. doi: 10.1002/9781119125556. devpsy406.

Masten, A. S., \& Coatsworth, J. D. (1998). The development of competence in favorable and unfavorable environments: Lessons from research on successful children. American Psychologist, 53(2), 205-220. doi:10.1037/0003-066X.53.2.205.

Masten, A. S., \& Powell, J. L. (2003). A resilience framework for research, policy, and practice. Resilience and Vulnerability, 1-26. doi:10.1017/CBO9780511615788.003.

McClelland, M. M., Morrison, F. J., \& Holmes, D. L. (2000). Children at risk for early academic problems: the role of learning-related social skills. Early Childhood Research Quarterly, 15(3), 307-329. doi:10.1016/S0885-2006(00)00069-7.

Musun Miller, L., \& Blevins Knabe, B. (1998). Adults' beliefs about children and mathematics: how important is it and how do children learn about it? Early Development and Parenting, 7(4), 191-202.

Mwangi C. N., Okatcha F. M., Kinai T. K., \& Ireri A. M. (2015). Relationship between academic resilience and academic achievement among secondary school students in Kiambu county, Kenya. International Journal of School and Cognitive Psychology, S2(003).doi:10.4172/2469-9837.S2-003.

Newbigging, K. (2018). Teaching children to be resilient could be key to their future mental health. Retrived from: https://www.weforum.org/agenda/2018/08/key-to-lifelong-goodmental-health-learn-resilience-in-childhood retrieved on 12.11.2019.

Newman,T . (2002). Promoting resilience: A review of effective strategies for child care services. Prepared for the Centre for Evidence-Based Social Services, University of Exeter. ISBN: 0-9535709-4-0.

OECD (2014). Strengthening resilience through education: PISA results. Meeting of the OECD Council at Ministerial level, 6-7 May, Paris.

Ogelman, H. G. (2015). Predictor effect of parental acceptance-rejection levels on resilience of preschool children. Procedia - Social and Behavioral Sciences, 174, 622-628. doi: 10.1016/j.sbspro.2015.01.592.

Ogelman, H. G., Secer, Z., Alabay, E., \& Ucar, F. (2012). Okul oncesi 5-6 yas grubu cocuklarin bilissel gelisimleri ile sosyal becerileri arasindaki iliskinin incelenmesi. Suleyman Demirel Universitesi Sosyal Bilimler Enstitusu Dergisi, 1(15), 391-402.

Olcer, S. (2017). Science content knowledge of 5-6 year old preschool children. International Journal of Environmental \& Science Education, 12( 2), 143-175.

Onat, G. (2010). Demokratik ve otoriter olarak algilanan ana-baba tutumlarinin lise birinci sinif ogrencilerinin yilmazlik duzeyine etkilerinin arastirilması (Master's thesis). YÖK National Thesis Center is obtained from the database. (Thesis No: 278780). 
Ozer, Y., \& Anil, D. (2011). Ogrencilerin fen ve matematik basarilarini etkileyen faktorlerin yapisal esitlik modeli ile incelenmesi. Hacettepe Universitesi Egitim Fakultesi Dergisi, 41, 313-324.

Peters, S. (1998).Playing games and learning mathematics: the results of two intervention studies. International Journal of Early Years Education, 6(1), 49-58. doi:10.1080/0966976980060105.

Polat Unutkan, O. (2007). Okul oncesi donem cocuklarinin matematik becerileri acisindan ilkogretime hazir bulunuslugunun incelenmesi. Hacettepe Universitesi Egitim Fakultesi Dergisi, 32, 243-254.

Ramazan, O., \& Demir, S. (2011). Okul oncesi egitim kurumuna devam eden 36-48 aylik cocuklarin bilissel gelisim duzeyleri. Egitim Bilimleri Arastirma Dergisi, 1(2), 83-98.

Richardson, G. E., Neiger, B. L., Jensen, S., \&. Kumpfer, K.L. (1990) The resiliency model, Health Education, 21(6), 33-39. doi:10.1080/00970050.1990.10614589.

Sahan Aktan, B., \& Onder, A. (2018). Okul oncesi donemde psikolojik dayaniklilik. Egitim Kuram ve Uygulama Arastirmalari Dergisi, 4(2), 20-30.

Sakakibara, T. (2014). Mathematics learning and teaching in Japanese preschool: providing appropriate foundations for an elementary schooler's mathematics learning. International Journal of Educational Studies in Mathematics, 1(1), 16-26.

Saral, S. (1993). Ozel Trabzon Ata koleji ogrencilerinin uyum duzeyleri ile akademik basarilari arasindaki iliskinin arastirilmasi (Master's thesis). YÖK National Thesis Center is obtained from the database. (Thesis No: 54577 ).

Sezer, T. (2008). Okul oncesi egitimi alan bes yas grubu cocuklara sayi ve islem kavramlarini kazandirmada drama yonteminin etkisinin incelenmesi (Master's thesis). YOK National Thesis Center is obtained from the database. (Thesis No: 216941).

Starkey, P., Klein, A., \& Wakeley, A. (2004). Enhancing young children's mathematical knowledge through a pre-kindergarten mathematics intervention. Early Childhood Research Quarterly, 19(1), 99-120.

Sun, J., \& Stewart, D. (2007). Age and gender effects on resilience in children and adolescents. International Journal of Mental Health Promotion, 9(4), 16-25. doi:10.1080/14623730.2007.9721845.

Tan, M., \& Temiz, B. K. (2003). Fen ogretiminde bilimsel surec becerilerinin yeri ve onemi. Pamukkale Universitesi Egitim Fakultesi Dergisi, 1(13), 89-101.

Taskin, N. (2013). Okul oncesi donemde matematik ile dil arasindaki iliski uzerine bir inceleme (Docrotal dissertation). YOK National Thesis Center is obtained from the database. (Thesis No: 307624).

Tastepe, T. (2012). Erken cocukluk donemi fen ve matematik egitimi icerik standartlari degerlendirme araclarinin gelistirilmesi (Master's thesis). YOK National Thesis Center is obtained from the database. (Thesis No: 331670 )

Tastepe, T., \& Temel, Z. F. (2013). Erken cocukluk donemi fen ve matematik egitimi icerik standartlari degerlendirme araclarinin gelistirilmesi (gecerlik ve guvenirlik calismalari). Kastamonu Egitim Dergisi, 21 (4), 1625-1640.

Terzi, S. (2000). Ilkogretim okulu altinci sinif ogrencilerinin kisilerarası problem cozme beceri algilarinin bazi degiskenler acisindan incelenmesi. Unpublised Master Thesis. Gazi University, Ankara.

VanderVen K. (2008). Promoting Positive Development in Early Childhood. Springer, (Chapter 9). USA.

Werner, E. E. (1993). Risk, resilience, and recovery: Perspectives from the Kauai longitudinal study. Development and Psychopathology, 5(04), 503-515. doi:10.1017/so95457940000612X. 
Zheng, P., \& Libertus, M. (2018). The role of parental education, household income, and race on parents' academic beliefs and the provision of home learning opportunities for 4to 8-year-old children. Journal of Educational and Developmental Psychology, 8(1), 118132. doi:10.5539/jedp.v8n1p118.

Zolkoski, S. M., \& Bullock, L. M. (2012). Resilience in children and youth: A review. Children and Youth Services Review, 34(12), 2295-2303.doi: 10.1016/j.childyouth. 2012.08.009.

\section{Biographical notes:}

Merve Unal completed her bachelor's degree at the Inonu University Faculty of Education in 2003, master degree on preschool education at the Inonu University in 2006 and PhD degree on child development and education at the Ankara University in 2014. She works areas are early childhood education, science and math education in early childhood, problem solving skills in early childhood. She has been working as a lecturer at Inonu University since 2004.

Yasin Tok completed his bachelor's degree in 2012 at Karadeniz Technical University, Fatih Faculty of Education. He has been a preschool teacher since 2012. He graduated from Inonu University Preschool Education Department with a master's degree in 2020. 